\author{
J-ABDIPAMAS (Jurnal Pengabdian Kepada Masyarakat) \\ Vol. $4 \bullet$ No. $1 \bullet 2020$ \\ ISSN : 2581-1320 (Print) ISSN : 2581-2572 (Online) \\ Homepage: http://ejurnal.ikippgribojonegoro.ac.id/index.php/J-ABDIPAMAS
}

\title{
PELATIHAN INOVASI KEMASAN PADA INDUSTRI MAKANAN DI DESA RACI TENGAH KABUPATEN GRESIK
}

\author{
Dewie Tri Wijayati Wardoyo ${ }^{1}$, Trias Madanika Kusumaningrum ${ }^{2}$, Hujatullah \\ Fazlurrahman ${ }^{3}$, Achmad Kautsar ${ }^{4}$, Hafid Kholidi Hadi ${ }^{5}$ \\ ${ }^{1}$ Universitas Negeri Surabaya. Email: dewiewijayati@unesa.ac.id \\ 2Universitas Negeri Surabaya. Email: triaskusumaningrum@unesa.ac.id \\ 3Universitas Negeri Surabaya. Email: hujjatullahfazlurrahman@unesa.ac.id \\ 4Universitas Negeri Surabaya. Email: achmadkautsar@unesa.ac.id \\ 5Universitas Negeri Surabaya. Email: hafidhadi@unesa.ac.id
}

\begin{abstract}
SME Foods that become partners of this activity have produced the product well, but the packaging used is still simple to less attract consumer interest. Besides, there are regulations from the Ministry of Health that food products from SMEs circulating on the market must have a PIRT number. Based on the results of the survey, SMEs food in the village of Raci Tengah does not know how the PIRT registration flow or its requirements. But some of the requirements in selling a product such as packaging must have a label that contains important information, but according to the team's monitoring at the time of survey, the label that the SMEs made food still does not contain all of the information. The training and mentoring method was chosen to provide insight and knowledge of SME owners so that they immediately have PIRT and packaging in accordance with the times. Overall the effectiveness of this activity was able to mobilize $82.6 \%$ of partners to carry out the results of the training. This result was quite satisfying from the team's target of only 70\%. The results of the mentoring of this activity can be input for the village head of Raci Tengah to always provide training and assistance to improve the competitiveness of food / beverage SMEs in the village.
\end{abstract}

Keywords: SMEs Food, Packaging, PIRT

\begin{abstract}
ABSTRAK
UKM makanan yang menjadi mitra kegiatan ini sebenarnya telah memproduksi produk dengan baik, namun kemasan yang digunakan masih sederhana sehingga kurang menarik minat konsumen. Selain itu terdapat peraturan dari Kementerian Kesehatan bahwa produk makanan dari UKM yang beredar di pasaran harus memiliki nomor PIRT. Berdasarkan hasil survei, UKM makanan di Desa Raci Tengah belum tahu bagaimana alur pendaftaran PIRT maupun persyaratannya. Namun beberapa persyaratan dalam menjual sebuah produk diantaranya kemasan harus memiliki label yang memuat informasi penting, namun menurut pantauan tim pada saat survei, label yang dibuat UKM makanan masih belum memuat semua informasi tersebut. Metode pelatihan dipilih untuk memberikan wawasan dan pengetahuan pemilik UKM agar segera memiliki PIRT dan kemasan yang sesuai dengan perkembangan zaman. Secara keseluruhan keefektifan kegiatan ini adalah mampu menggerakkan 82,6\% mitra untuk menjalankan hasil pelatihan. Hasil tersebut cukup memuaskan dari target tim yang hanya 70\%. Hasil pendampingan kegiatan ini dapat menjadi masukkan bagi para kepala desa Raci tengah untuk senantiasa memberikan pelatihan-pelatihan serta pendampingan guna meningkatkan daya saing dari UKM makanan/minuman yang ada di desa tersebut.
\end{abstract}

Kata Kunci: UKM Makanan, Kemasan, PIRT 


\section{PENDAHULUAN}

Kemasan berfungsi sebagai alat yang berguna untuk melindungi produk/barang yang ada di dalamnya (Kotler \& Keller, 2014). Material kemasan menjadi salah satu penentu keberadaan kualitas produk/barang, ketika sudah mulai diedarkan ke masyarakat. Seiring dengan perkembangan teknologi informasi dan komunikasi, saat ini kemasan bukan hanya selau dilihat dari sisi kekuatan materialnya saja, namun juga mengarah pada tampilan visualnya. Ketika berbicara mengenai komponen visual pada kemasan, maka beberapa unsur yang melekat pada kemasaran tersebut, menjadi menarik untuk diperbincangkan. Kemasan menjadi senjata pertama yang mempertemukan antara produk dan konsumennya.

Sebagaimana menurut Kodir et al (2020) disebutkan bahwa kemasan saat ini menjadi faktor yang penting sebagai alat pemasaran. Kemudian, Label sebelumnya disebut dengan istilah Etiket (dalam Bahasa Perancis: etiquette) menurut kamus berarti merek, potongan kertas pada kemasan/etiket barang, yang berisi tentang keterangan mengenai isi barang yang dikemas. Merek/branding mempunyai pengertian lebih luas dari pengertian etiket. Ketika etiket ditempel pada pembungkus atau kemasan sering juga disebut dengan label. Bahan etiket sangat beragam, mulai dari kertas, plastik, kain, dan lain-lain. Perkembangan selanjutnya, label ini tidak ditempelkan melainkan dicetak langsung pada kemasannya. Etiket sesungguhnya adalah alat komunikasi visual, karena terdiri dari beberapa informasi dan gagasan tentang suatu produk, yang menghubungkan antara produsen dengan khalayak. Kesadaran konsumen dianggap sebagai langkah awal yang harus dicapai dalam usaha penjualan sebuah produk. Sebagai satu bentuk komunikasi visual, yang merupakan bagian dan alat periklanan, khususnya periklanan cetak, etiket memberikan pemahaman dan citra kepada kalayaknya, atas karakteristik, daya tarik, dan perbedaan dengan merek-merek lain. Saat ini, geliat masyarakat untuk melakukan usaha secara mandiri sangatlah tinggi (Fazlurrrahman dan Untarini, 2019). Dinas Perindustrian dan Perdagangan maupun instansi pemerinah yang lain, memiliki program yang mengarah pada start up bussines. Beberapa masyarakat yang berminat untuk berwirausaha, mengawali dengan mengusung potensi dan ciri khas masing-masing daerah, salah satunya adalah sektor makanan dan minuman.

Industry makanan adalah menjadi salah satu yang cukup kuat ditempa badai karena manusia kecenderungan yang konsumtif, serta makan dan minum merupakan kebutuhan sehari-hari, maka sektor makanan dan minuman menjadi sektor yang banyak diminati oleh pelaku UMKM (Usaha Mikro, Kecil, dan Menengah) di berbagai tempat di Indonesia (Wardoyo et al, 2018). Kabupaten gresik merupakan salah satu kabupaten yang berada di wilayah tapalkuda Jawa Timur kalau ditinjau dari ibu kotanya yaitu Surabaya di kota Gresik ini sangat potensi sekali pengembangan UKM dikarenakan kota ini menjadi kota yang sering kali terlewati oleh pengunjung dari kota lain yang ingin ke kota Surabaya dan sebaliknya dari Surabaya yang ingin ke kota- kota lain seperti lamongan, Tuban, Bojonegoro sampai Jawa Tengah sehingga menjadikan masyarakat Kota Gresik harus sering melakukan inovasi usaha yang ujungnya guna menbantu meningkatkan perekonomian daerah dan secara khusus ekonomi masyarakat itu sendiri dari latar belakang inilah kami para pengeliat perekonomian masyarakat sebagai insan akademis 
terketuk untuk melakukan pengabdian bagi masyarakat gersik secara umum dan khususnya pada UKM yang melakukan usaha di bidang makanan yang dalam hal ini masih banyak yang belum memperhatikan pentingnya peran kemasan dalam memasarkan produk usahanya.

Produk dari industri makanan sebelum dijual ke masyarakat, diperlukan pengamatan terlebih dahulu terutama dalam hal rasa maka setelah itu kemasan juga menjadi suatu yang sangat penting guna tercapainya hasil yang terbaik entah dalam rasa maupun keuntungan. Keuntungan yang diinginkan seorang produksen juga haruslah melakukan inovasi-inovasi produk hal ini karena persaingan sangatlah kuat minimal seorang pengusaha atau produsen meningkatan kualitas produk, mengurangi biaya-biaya produksi dan operasi serta meningkatkan produktivitas tenaga kerjanya. Inovasi Produksi adalah suatu kegiatan untuk melakukan perubahaan dalam produksi supaya dapat menekan biaya produksi dan operasional, memperbanyak jumlah produksi dan meningkatkan kualitas produk, mengusahakan produksi dapat berjalan dengan seefisien dan se-efektif mungkia (Rangkuti,2005) .

Inovasi adalah suatu proses dan/ atau hasil pengembangan pemanfaatan suatu produk/ sumber daya yang telah ada sebelumnya, sehingga memiliki nilai yang lebih berarti. Menurut UU No. 19 Tahun 2002, pengertian inovasi adalah suatu kegiatan penelitian, pengembangan, dan atau perekayasaan yang dilakukan untuk pengembangan penerapan praktis nilai dan konteks ilmu pengetahuan yang baru, atau pun cara baru untuk menerapkan ilmu pengetahuan dan teknologi yang sudah ada ke dalam produk atau pun proses produksinya. Ada juga yang mengatakan arti inovasi adalah suatu pembaharuan terhadap berbagai sumber daya sehingga sumber daya tersebut mempunyai manfaat yang lebih bagi manusia (Kotler \& Keller 2014). Proses inovasi sangat dipengaruhi oleh kemajuan teknologi dan ilmu pengetahuan karena kedua hal tersebut dapat memudahkan dalam memproduksi sesuatu yang baru dan berbeda (Sofjan, 2004). Pada dasarnya manfaat inovasi adalah untuk menyempurnakan atau meningkatkan fungsi dari pemanfaatan suatu produk atau sumber daya sehingga manusia mendapatkan manfaat yang lebih. Inovasi terjadi di berbagai bidang kehidupan, mulai dari dunia bisnis, pendidikan, komunikasi, dan lain sebagainya. Inovasi dalam hal ini menbahas tentang pentingnya inovasi kemasan sehingga produk terlihat atau terkesan menarik yang pada ujungnya meningkatkan nilai jual dengan nilai jual tinggi juga harus tidak lupa menperhatikan pula kemasan dan bentuk dan juga rasa dari produk yang dihasilkan semua ini juga tidak bisa para produksen meninggalkan legimasi dan pengakuan yang harus di percayai oleh konsumen yaitu masrakat oleh karenanya diprerlukan pula Perizinan PIRT (Pangan Industri Rumah Tangga) terutama untuk produk jenis makanan/minuman. Izin ini penting karena sebagai jaminan bahwa usaha makanan/minuman rumahan yang dijual memenuhi standar produk pangan yang berlaku (Kanal Pengetahuan, 2019).

Izin PIRT hanya diberikan kepada produk pangan olahan dengan tingkat resiko yang rendah dengan menerbitkan nomor PIRT sebanyak 15 digit (baru) dan 12 digit (lama) yang berlaku selama 5 tahun dan dapat diperpanjang untuk makanan dan minuman yang daya tahannya di atas 7 hari, sedangkan makanan dan minuman yang memiliki daya tahan 
di bawah 7 hari termasuk golongan Layak Sehat Jasa Boga dan izin PIRT hanya berlaku 3 tahun dan dapat diperpanjang. Lama waktu proses pengurusan izin PIRT, 1 minggu - 3 bulan, tergantung masing-masing daerah. Pengurusan Izin P-IRT (Industri Rumah tangga) memberikan beberapa keuntungan, yaitu Pengusaha bisa dengan tenang mengedarkan dan memproses produksi secara luas dengan resmi. Jika pada suatu saat petugas dari Dinas Kesehatan melakukan survei dan mendapati industri skala rumah tangga tersebut memerlukan beberapa alat untuk menunjang pekerjaan ataupun untuk efisiensi; Pihak Dinas Kesehatan akan menyumbangkan alat penunjang industri yang dibutuhkan tanpa memungut biaya; Dengan pencantuman kode IRT, makanan dan minuman akan lebih mudah dipasarkan dan lebih disukai konsumen hingga bisa meningkatkan daya jual; Menghindari sanksi administrasi atas kasus-kasus seperti: melanggar peraturan di bidang pangan, nama pemilik tidak sesuai dengan yang ada di sertifikat, produk tidak aman dan tidak layak dikonsumsi.

Hasil survey pada UKM makanan di Desa Raci Tengah Kecamatan Sidayu Kabupaten Gresik menunjukkan jumlah UKM makanan kurang lebih berjumlah 30 UKM. Produk yang diproduksi diantaranya Petulo Goreng dan Stick Keju. UKM makanan yang menjadi mitra PKM sebenarnya telah memproduksi produk dengan baik, namun kemasan yang digunakan masih sederhana sehingga kurang menarik minat konsumen. Selain itu terdapat peraturan dari Kementerian Kesehatan bahwa produk makanan dari UKM yang beredar di pasaran harus memiliki nomor PIRT. Berdasarkan hasil survei, UKM makanan di Desa Raci Tengah belum tahu bagaimana alur pendaftaran PIRT maupun persyaratannya. Adapun salah beberapa persyaratan yaitu kemasan harus memiliki label yang memuat informasi penting, namun menurut pantauan tim pada saat survei, label yang dibuat UKM makanan masih belum memuat semua informasi tersebut oleh karenanya harapan PKM yang dilakukan ini berdampak positif khususnya bagi UKM yang bergerak secara khusus pada produksi makanan di Kabupaten Gresik. Pengabdian masyarakat ini bertujuan untuk meningkatkan kreatifitas UKM industri makanan melalui workshop kemasan untuk salah satu syarat pengajuan PIRT.

\section{METODE PELAKSANAAN}

Program Pengabdian kepada Masyarakat ini menggunakan metode pendekatan berupa pelatihan terpadu. Pendekatan pelatihan yang diberikan diawali dengan pemberian materi inovasi kemasan, materi labeling untuk syarat pengajuan PIRT, alur perijinan PIRT, dan materi bahan tambahan pangan yang aman untuk industri makanan.

Kegiatan pengabdian masyarakat ini terdiri dari dari beberapa tahap:

\section{Persiapan,}

a. tim berkoordinasi dengan perangkat desa untuk tanggal, waktu, tempat, dan peserta

b. pelaksanaan workshop kemasan.

\section{Pelaksanaan}

a. Kegiatan dilaksanakan sesuai jadwal yang direncanakan. 
b. Narasumber memberikan materi (inovasi, kemasan, labeling, mengajuan izin PIRT, dan tambahan pangan) dengan baik.

c. Audiens dan pemilik UKM, secara aktif selama mengikuti kegiatan pelatihan sehingga mereka mengenali dan mengetahui desain kemasan yang baru.

d. Sarana dan fasilitas yang disediakan cukup baik

e. Akhir sesi, audience diminta untuk mengisi kuesioner

\section{Pendampingan}

a. Pemilik UKM kembali disurvei dan dilihat progresnya

b. Membuat laporan akhir

c. Membuat publikasi media massa online dana artikel

Adapun data yang digunakan dalam penelitian ini diperoleh dari observasi dan wawancara. Mitra dalam pengadian masyarakat ini adalah UKM industri makanan di Desa Raci Tengah Kabupaten Gresik.

\section{HASIL DAN PEMBAHASAN}

Materi yang pertama kali disampaikan dalam workshop yaitu mengenai desain kemasan. Seiring dengan perkembangan zaman yang berbasis teknologi informasi dan komunikasi, saat ini kemasan tidak ditinjau hanya dari sisi kekuatan matrialnya, namu juga mengarah pada tampilan visualnya. Kemasan menjadi senjata pertama yang mampu mempertemukan antara produk dan konsumennya sehingga kemasan saat ini menjadi faktor yang penting sebagai alat pemasaran.

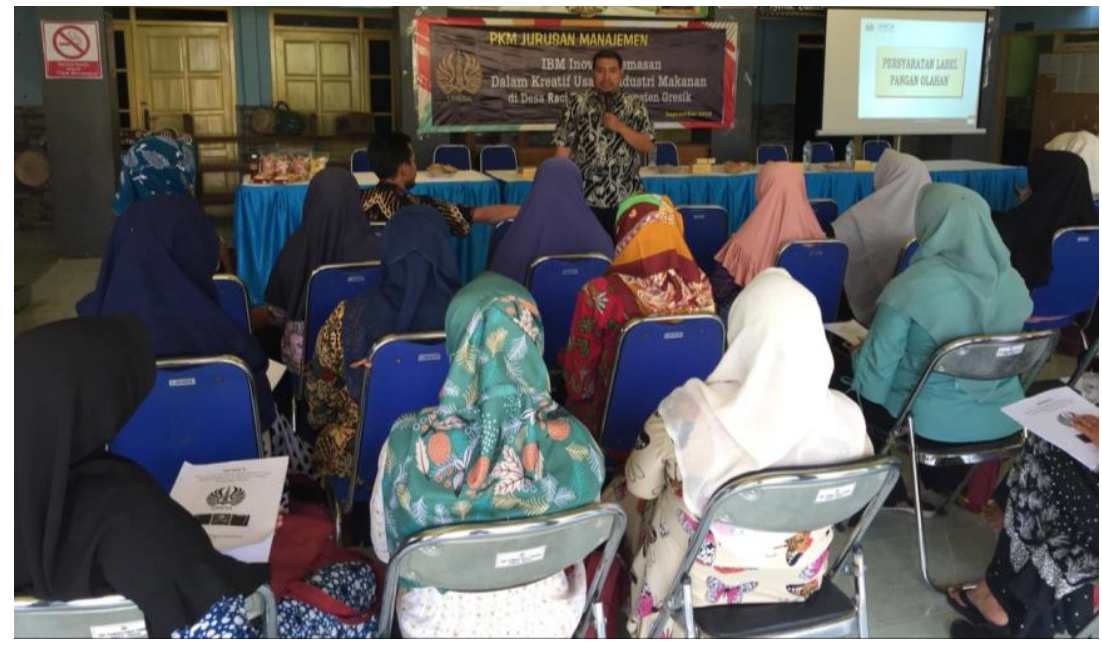

Gambar 1. Penyampaian materi desain kemasan

Berdasarkan hasil survey awal seperti gambar 2 di bawah ini, menunjukkan bahwa mayoritas audiens belum merasa kemasannya menarik konsumen karena banyak yang masih sederhana hanya menggunakan plastik dan cetakan label yang sederhana. Sehingga materi pertama ini dirasa tepat dalam menyelesaikan masalah tersebut. 


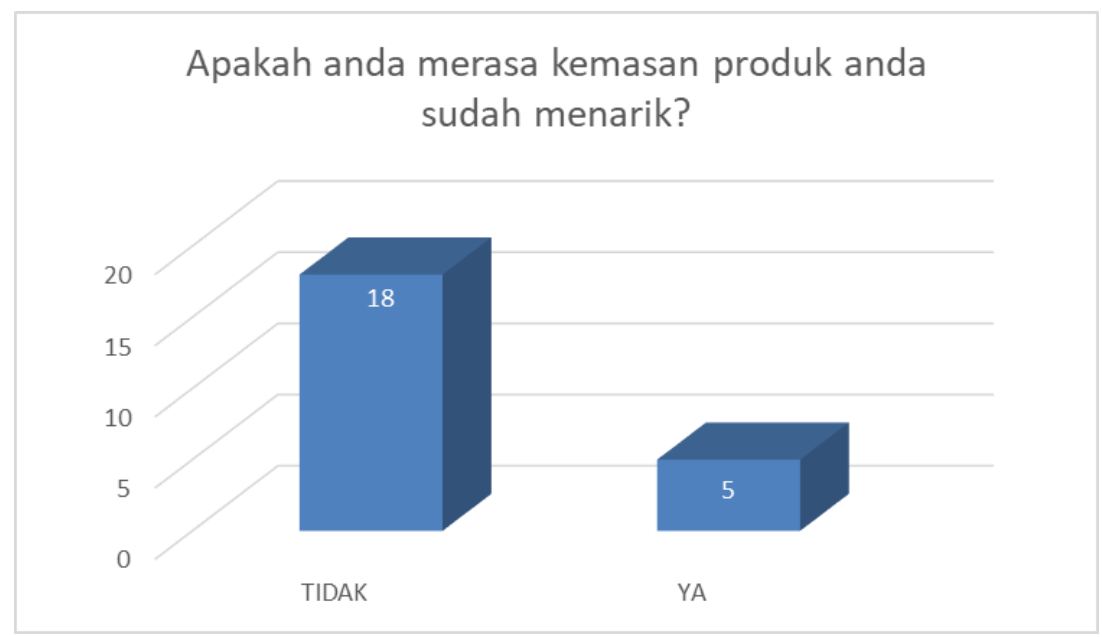

Gambar 2. Hasil angket terkait kemasan produk

Pengukuran ketercapaian pelatihan materi pertama ini, dapat dilihat pada hasil gambar 3 di bawah ini. 19 audiens $(82,6 \%)$ sangat setuju bahwa materi pertama ini sangat bermanfaat baginya, 3 audiens (13,0\%) diantaranya merasa setuju, dan hanya 1 audiens $(4,4 \%)$ yang merasa tidak setuju. Adapun yang merasa tidak setuju dikarenakan sebelumnya audiens tersebut telah mendapat materi serupa dari Disperindag dan telah mencoba memperbaiki kemasannya. Namun mayoritas audiens merasa materi pertama ini sangat bermanfaat. Pengukuran berikutnya adalah cara penyampaian narasumber dan cara menjawab narasumber terhadap pertanyaan yang diajukan audiens. Hasil menunjukkan bahwa 16 audiens (69,5\%) sangat setuju bahwa penjelasan narasumber mudah dimengerti dan sisanya 7 audiens $(30,5 \%)$ merasa setuju.

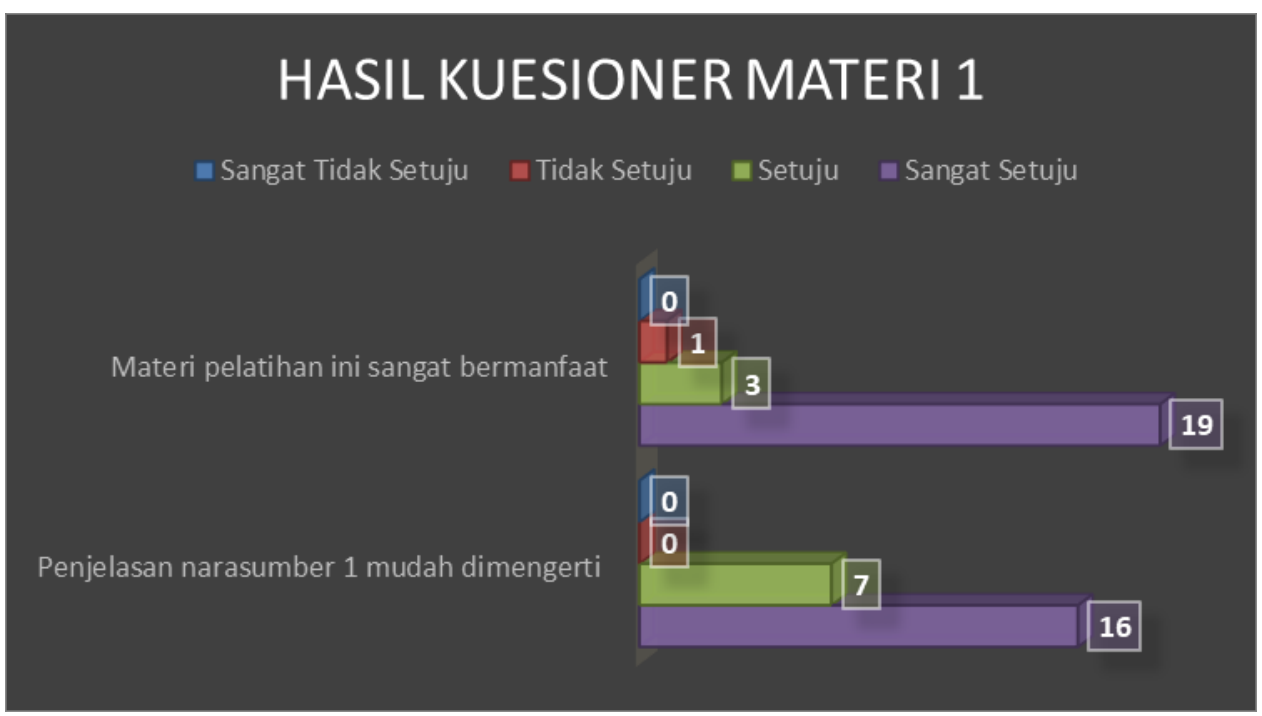

Gambar 3. Hasil kuesioner materi desain kemasan

Materi kedua mengenai labeling untuk syarat pengajuan PIRT dan alur perijinan PIRT. Setiap keterangan mengenai pangan yg berbentuk gambar, tulisan, kombinasi keduanya, yg disertakan pada pangan, dimasukkan ke dalam pangan, ditempelkan pada/dicetak pada produk atau merupakan bagian kemasan pangan harus memenuhi: (1) 
Undang Undang RI No.18 Tahun 2012 Tentang Pangan, (2) Undang Undang RI No. 8 Tahun 1999 Tentang Perlindungan Konsumen, (3) Peraturan Pemerintah RI No. 69 Tahun 1999 Tentang Label Dan Iklan Pangan. Dimana komposisi label yang akan diajukan untuk pengurusan PIRT harus terdiri dari nama produk, daftar bahan yang digunakan, berat bersih, nama \& alamat yang memproduksi atau memasukkan ke indonesia, keterangan halal, tanggal, bulan dan tahun kadaluarsa, dan nomor pendaftaran/ijin edar.

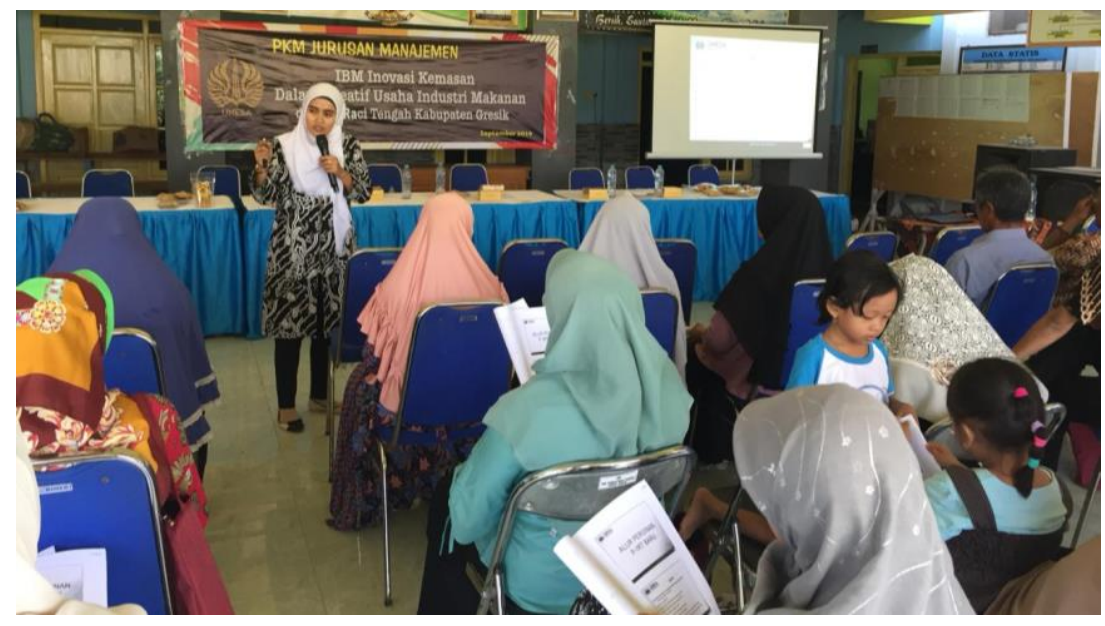

Gambar 4. Penyampaian materi labeling untuk syarat pengajuan PIRT

Pengukuran ketercapaian pelatihan materi kedua ini, dapat dilihat pada hasil gambar 5 di bawah ini. 13 audiens (56,5\%) sangat setuju bahwa materi pertama ini sangat bermanfaat baginya, 9 audiens (39,1\%) diantaranya merasa setuju, dan hanya 1 audiens $(4,3 \%)$ yang merasa tidak setuju. Adapun yang merasa tidak setuju dikarenakan mereka telah punya PIRT dan labelingnya dirasa telah memenuhi syarat. Namun mayoritas audiens merasa materi pertama ini sangat bermanfaat sehingga mereka akan mengaplikasikannya dalam pengajuan PIRT kedepannya. Pengukuran berikutnya adalah cara penyampaian narasumber dan cara menjawab narasumber terhadap pertanyaan yang diajukan audiens. Hasil menunjukkan bahwa 18 audiens (78,3\%) sangat setuju bahwa penjelasan narasumber mudah dimengerti dan sisanya 5 audiens (21,7\%) merasa setuju.

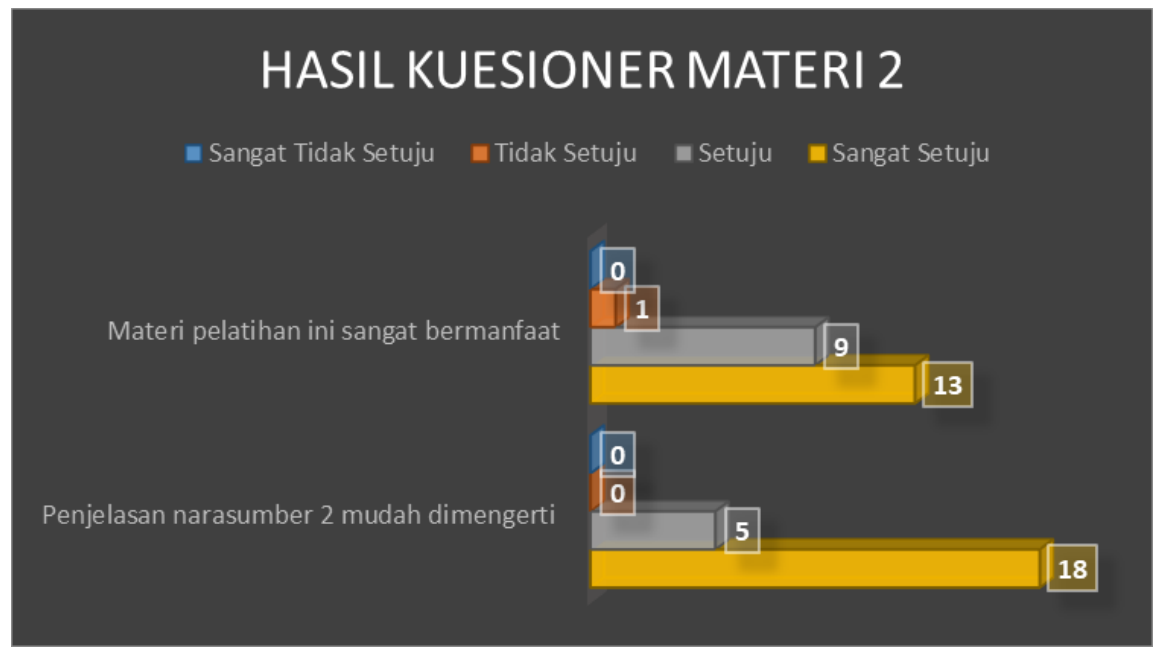

Gambar 5. Hasil kuesioner materi labeling untuk syarat pengajuan PIRT 
Tahap ketiga yaitu pendampingan yang dilakukan dengan mekanisme diskusi dengan mitra tentang implementasi hasil pelatihan dan penerapan secara singkat. Pendampingan dilakukan tanggal 19-20 September 2019 ke perwakilan UKM di Desa Raci Tengah. Pada kegiatan pendampingan dilakukan penarikan post test dimana pre test telah dilakukan sebelum pelatihan. Hasilnya pada gambar 6 bawa saat sebelum pelatihan hanya ada 10 audies yang tahu bahwa labeling adalah kelengkapan pengajuan PIRT dan penting untuk memiliki ciri label yang sesuai ketentuan, pada saat pendampingan, kesemua pemilik UKM (23 audiens) telah mengetahui bahwa labeling itu penting. Pengukuran berikutnya menunjukkan bahwa sebelum pelatihan hanya ada 6 audiens yang telah mencoba mendesain kemasan produknya, sisanya masih sederhana, pada saat pendampingan, 19 audiens $(82,6 \%)$ telah mendesain kemasannya supaya lebih menarik, dan sisanya 4 audiens $(17,4 \%)$ belum melakukan hasil pelatihan.

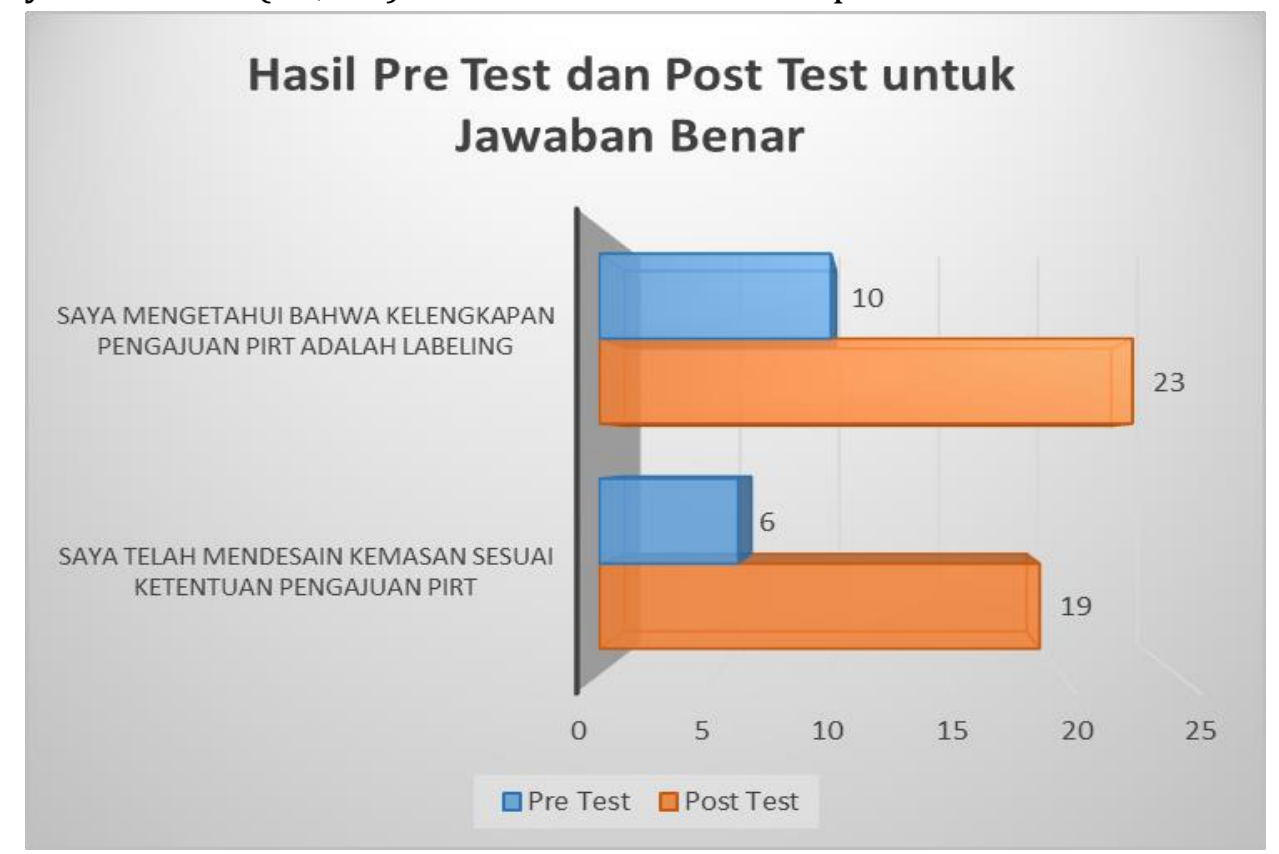

Gambar 6. Hasil pre test dan post test

\section{SIMPULAN}

Pelaksanaan kegiatan pengabdian kepada masyarakat di Desa Raci Tengah, Gresik sudah berjalan dengan baik dan lancar. Hasil dari pelaksanaan kegiatan tersebut semua tahapan pelaksanaan kegiatan berjalan sesuai dengan yang direncanakan. Adanya partisipasi aktif saat pelatihan dan pendampingan dapat menjadi dasar bahwa pelatihan di materi lain sangat dibutuhkan mitra. Secara keseluruhan keefektifan kegiatan ini adalah mampu menggerakkan $82,6 \%$ mitra untuk menjalankan hasil pelatihan. Hasil tersebut cukup memuaskan dari target tim yang hanya $70 \%$.

Hasil pendampingan kegiatan ini dapat menjadi masukkan bagi para kepala desa Raci tengah untuk senantiasa memberikan pelatihan-pelatihan serta pendampingan guna meningkatkan daya saing dari UKM makanan/minuman yang ada di desa tersebut. Adapun evaluasi bagi tim adalah perlunya kordinasi lebih banyak kesempatan dengan mitra sehingga segala hambatan yang dialami peserta pelatihan dapat ditangani secara cepat. 


\section{DAFTAR RUJUKAN}

Assauri, S. (2004). Manajemen produksi dan operasi, edisi revisi. Lembaga Penerbit Fakultas Ekonomi Universitas Indonesia: Jakarta.

Fazlurrahman, H., Untarini, N. (2019). Comparing Of entrepreneurial intention student between science and humanities students: A literature review. Scholars Journal of Economics, Business, and Management, 6(2).

Kanal pengetahuan. (2019). Pengurusan perizinan PIRT pangan industri rumah tangga. Diakses pada tanggal 5 April 2019 pukul 15.08 dari https://www.kanal.web.id/pengurusan-perizinan-pirt-pangan-industri-rumahtangga.

Kotler, P. and Keller, K. (2014). Marketing management. 15th edition. Prentice Hall: Saddle River.

Kodir, A., Islam, M. A., Pradana, G. W., Kusumaningrum, T. M., Rozaq, K. (2020). Pendampingan Penyusunan Standard Operational Procedure (SOP) dan desain kemasan bagi IKM makanan di Kabupaten Kediri dan Kota Batu. Abimanyu: Journal of Community Engagement, 1(1), 1-9.

Wardoyo, D. T. W., Iriani, S. S., Kautsar, A. (2018). Adoption of e-commerce, entrepreneurship orientation mediated by business strategy on the performance food industries. International Journal of Civil Engineering and Technology, 9(5), 896902. 
92 J-Abdipamas, Vol. 4, No. 1 April, 2020 